\title{
Effects of Coronavirus (COVID-19) Pandemic on Health Anxiety Levels of Healthcare Professionals
}

\section{Coronavirüs (COViD-19) Salgınının Sağlık Çalışanlarının Sağlık Kaygıları Düzeylerine Etkileri}

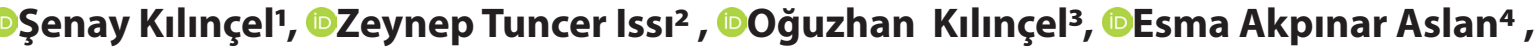

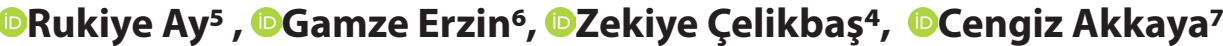 \\ 'Sakarya Child and Adolescent Psychiatry İnstitute, Sakarya, Turkey \\ 2Sakarya University Faculty of Medicine, Department of Algology, Sakarya, Turkey \\ ${ }^{3}$ Sakarya Yenikent State Hospital, Department of Psychiatry, Sakarya, Turkey \\ ${ }^{4}$ Gaziosmanpasa University Faculty of Medicine, Department of Psychiatry, Tokat, Turkey \\ ${ }^{5}$ Bursa Yüksek İhtisas Traning and Research Hospital, Department of Psychiatry, Bursa, Turkey \\ ${ }^{6}$ Ankara Dışkapı Training and Research Hospital, Department of Psychiatry, Ankara, Turkey \\ 7Uludağ University Faculty of Medicine, Department of Psychiatry, Bursa, Turkey
}

\begin{abstract}
Objective: We aimed to determine the effects of the COVID-19 outbreak on health workers' health concerns and life.

Methods: The study included 293 healthcare professionals reached via e-mail. A questionnaire created by researchers and health anxiety inventory were applied online to all participants. The questionnaire questions investigated the sociodemographic characteristics of the participant, whether he received psychological support during the COVID-19 outbreak, whether he had a chronic disease, whether he had problems with the care of his children, whether he was actively involved in the COVID clinic / service, and how his social and work life was affected.

Results: Participants consisted of 73 doctors, 145 nurses and 75 other healthcare professionals (OHP). It was determined that the COVID-19 test was performed to the healthcare personnel in the risk group at a very low rate $(1.4 \%)$. The number of people receiving psychiatric support during the COVID-19 outbreak was 59 (20.1\%). It was determined that the COVID-19 outbreak affected business life of the healthcare and social life of healthcare professionals very much and significantly $(p<0.05)$. During the COVID-19 outbreak, it was determined that the desire to work in 142 (48.5\%) workers decreased. Due to news about COVID-19 outbreak on social media, 226 (77.1\%) people were found to have increased health anxiety. The total score of the health anxiety inventory was found to be statistically significantly higher in the nurse and other healthcare professionals (OHP) group compared to the doctor group ( $p=0.013$ and $p=0.005$, respectively).

Conclusion: Our study is the first study in our country to evaluate the health concerns of COVID-19 outbreak and their effects on life. In addition to the physical health of healthcare professionals, necessary protective and supportive spiritual-social measures should be taken in order to protect their mental health in terms of providing a functional service.
\end{abstract}

Keywords: COVID-19, health anxiety, pandemic
Öz

Amaç: Bu araşıırma ile COVID-19 salgınının sağlık çalışanlarının sağlık kaygıları ve yaşamları üzerine etkilerini belirlemeyi amaçladık.

Yöntem: Araştırmaya, e-mail yoluyla ulaşılan 293 sağ ık çalışanı dahil edildi. Tüm katılımcılara araștırmacılar tarafından oluşturulmus bir anket ve devamında sağlık kaygısı envanteri online olarak uygulandı. Anket soruları ile katılımının sosyodemografik özellikleri, COVID-19 salgını süresince ruhsal destek alıp almadığı, kronik hastalığı olup olmadığı, çocuklarının bakımılla ilgili sorun yaşayıp yaşamadığı, COVID polikliniğinde/servisinde aktif görev alıp olmadığı, sosyal ve iş yaşantısının nasıl etkilendiği araştıııldı.

Bulgular: Katılımcıların 73'ü (\%24.9) doktor, 145'i hemşire ve 75'i (\%25.6) diğer sağıı personelinden oluşmaktadır. Katılımcıların yaş ortalaması $35.22 \pm 8.51$ ve çalışma süresi ortancası 10 (0.0-43.0) yıldır. Risk grubunda yer alan sağlık personeline covid-19 testinin çok az oranda (\%1.4) yapıldığı saptanmıştır. COVID-19 salgını sürecinde psikiyatrik destek alanların sayısı 59 (\%20.1)'dur. Katılımcılardan 99'u (\%33.9) COVID-19 salgını sürecinde çocuk bakımında problem yaşadığını belirtmiştir. COVID-19'un sağlık profesyonellerinin iş ve sosyal yaşamını önemli ölçüde etkilediği saptanmıştır ( $p<0.05)$. COVID-19 salgını süresince katılımcılardan 142 (\%48.5) kişide çalışma isteğinin azaldığı saptanmıştır. Sosyal medyada COVID-19 salgını hakkında yapılan haberlerden dolayı 226 (\%77.1) kişide sağlık kaygısının arttığı saptanmıştır. Sağlık anksiyete envanteri toplam puanının doktor grubuna kıyasla hemşire ve Diğer Sağlık Personeli (DSP) grubunda istatistiksel olarak anlamlı şekilde yüksek çıktığı saptanmıştır ( $p=0.013$ ve $p=0.005$, sırasıyla)

Sonuç: Çalışmamız ülkemizde COVID-19 salgınının sağlık çalışanlarının sağlık kaygııarı ve onların yaşamları üzerine etkilerinin değerlendirildiği ilk çalışmadır. Sağlık çalışanlarının fiziksel sağlıklarının yanı sıra, işlevsel bir hizmet verebilmeleri açısından ruhsal sağlıklarının da korunabilmesi için gerekli koruyucu ve destekleyici ruhsal-toplumsal önlemlerin alınması gerekmektedir.

Anahtar Kelimeler: COVID-19, sağlık kaygısı, salgın

Corresponding (ïletişim): : Şenay Kılınçel, Sakarya Child and Adolescent Psychiatry Institute, Sakarya, Turkey

E-mail (E-posta): senaykilincel@gmail.com

Received (Gelis Tarihi): 09.07.2020 Accepted (Kabul Tarihi): 08.09.2020 


\section{INTRODUCTION}

At the beginning of 2020, the 2019 coronavirus disease (COVID-19) first began to spread throughout Wuhan, China. [1] COVID-19 is an RNA virus from the coronavirus family that infects animals and humans, causing respiratory, gastrointestinal, hepatic and neurological diseases. ${ }^{[2]}$ On January 30, 2020, the World Health Organization announced that COVID-19 is an internationally concerned public health emergency. ${ }^{[3]}$ COVID-19 clinic can range from unspecified clinical course to severe respiratory failure and death. Common symptoms include fever, cough, muscle pain, fatigue, headache, diarrhea and hemoptysis. ${ }^{[4]}$

A rapidly increasing number of cases and deaths have started to bring psychiatric problems with healthcare professionals. 1 Anxiety and depression are the most common psychiatric conditions. ${ }^{[1,5]}$ COVID-19, the very high definition of infectiousness, led to increased feelings of uncertainty among healthcare professionals. In the early stage of the Severe acute respiratory syndrome (SARS) epidemic, a number of psychiatric disorders including persistent depression, anxiety, panic attacks, psychomotor excitement, psychotic symptoms have been reported. ${ }^{[6]}$ Additionally, in epidemics that cause deaths affecting the world, such as pandemic, the health system is among the hardest working institutions. In pandemics that affect society, socio-economic and spiritual aspects, the mental health of healthcare teams, whose social and business life of the healthcare responsibility is largely undertaken, is affected by this situation.

Health anxiety is the occurrence of excessive interpretation of the usual physical sensations in the person, although there is no physical illness. ${ }^{[7]}$ Health anxiety is also involved in the occurrence of anxiety disorders and shapes its clinical appearance as one of its components. ${ }^{[8]}$ Health anxiety has a special role especially in panic disorder and is effective in creating complications of panic disorder. In addition, physical symptoms and sensations that are involved in social phobia and obsessive-compulsive disorder also develop as a result of health anxiety. ${ }^{[8]}$

In this study, we aimed to determine the effects of the COVID-19 outbreak on health workers' health concerns and life.

\section{METHODS}

After the approval of Sakarya University Faculty of Medicine Clinical Research Ethics Committee, the study started. Health workers to be reached by e-mail were included in the research after the online questionnaire was created. An online questionnaire structured by researchers and health anxiety inventory were applied to all participants (Table 1 and 2). The participants were divided into three groups: doctors, nurses and the other health care workers (eg. psychologist, midwives, radiology technician ...)
Health Anxiety Inventory: It is a self-report scale developed by Salkovskis et al. ${ }^{[9]}$ and contains 18 items. The first 14 items with four options include questionnaires and side-by-side answers. In the remaining 4 items, it makes inquiries about the mental state of the patients with the assumption that they may have a serious illness. Scoring is between 0-3 for each item. A high score indicates a high level of health anxiety. The validity and reliability of the test was carried out by Aydemir et al. ${ }^{[7]}$ for the Turkish society.

\section{Statistical Analysis}

The data were analyzed with SPSS v25 software (SPSS Inc., USA). Kolmogorov-Smirnov test was used to check the compliance of the continuous variables to a normal distribution. Descriptive statistics were used to summarize the data on sociodemographic. Differences between groups were tested using chisquared tests, Mann-Whitney $U$ tests, Kruskal-Wallis tests, or univariate analysis of variance, as appropriate. Pearson and Spearman correlation analysis were used to evaluating the relationships between quantitative variables. Statistical significance was accepted as $p<0.05$.

\section{RESULTS}

The socio-demographic characteristics of the participants are shown in Table 1. A total of 293 healthcare professionals were included in our study. Participants consisted of 73 doctors, 145 nurses and 75 other healthcare professionals (OHP). The average age of the participants is $35.22 \pm 8.51$ years and the median of working time is 10 years (0.0-43.0). The number of men surveyed is $81(27.6 \%)$ and the number of women is 212 (72.4\%). It was determined that 209 (71.3\%) of the participants were married and 183 (62.3\%) had children (Table 1).

\begin{tabular}{|c|c|}
\hline & $\begin{array}{c}\text { Participants }(\mathrm{n}=293) \\
\text { Mean } \pm \text { Ss or Median (min-max) / N (\%) }\end{array}$ \\
\hline Age (year) & $35.22 \pm 8.51$ \\
\hline \multicolumn{2}{|l|}{ Gender } \\
\hline male & $81(27.6)$ \\
\hline female & $212(72.4)$ \\
\hline \multicolumn{2}{|l|}{ Marital status } \\
\hline single & $84(28.7)$ \\
\hline married & $209(71.3)$ \\
\hline \multicolumn{2}{|l|}{ Child status } \\
\hline yes & $183(62.3)$ \\
\hline no & $110(37.5)$ \\
\hline \multicolumn{2}{|l|}{ Profession } \\
\hline doctor & $73(24.9)$ \\
\hline nurse & $145(49.5)$ \\
\hline other health professionals & 75 (25.6) \\
\hline Working time (years) & $10(0.0-43.0)$ \\
\hline
\end{tabular}


The responses of the participants to the questions about the COVID-19 outbreak are shown in Table 2. It was determined that the COVID-19 pandemic affected the business life of the healthcare personnel too much in 113 (38.6\%) people, and evidently affected $100(34.1 \%)$ people $(p<0.05)$. It was determined that the COVID-19 pandemic affected the social life of the healthcare personnel too much in $82(28.0 \%)$ people, and evidently affected $134(45.7 \%)$ people $(p<0.05)$. During the Covid-19 outbreak, it was determined that the desire to work in $142(48.5 \%)$ workers decreased $(p<0.05)$. According to the news about the COVID-19 outbreak in social media, 226 (77.1\%) people were found to have increased health anxiety. It was determined that the total score of the health anxiety inventory of the participants was 16.00 (1$44)$, the negative results sub-score of the disease was 3.00 (0-12) and the physical symptoms sub-score was 13.00 (1-36) (Table 2).

Table 3 shows the comparisons of the participants according to working status in COVID-19 service. The number of healthcare workers having problems in childcare was significantly higher in COVID-19 service workers compared to non-COVID-19 service workers $(p=0.008)$. The effects of COVID-19 outbreak news on anxiety levels were significantly lower in COVID-19 service workers compared to nonCOVID-19 service workers $(p=0.046)$. In addition there was no statistically difference in health anxiety inventory between the COVID-19 service workers and non-COVID-19 service workers (Table 3).

Correlation analysis between the participants' health anxiety inventory total score and inventory sub-scores, work and social life effects are shown in Table 4. There was found statistically significant positive correlation between the health anxiety inventory total score and the parameters of receiving psychiatric support in COVID-19 outbreak, hand washing habit during COVID-19, and shopping for excessive food and cleaning materials $(P<0.001, r: 0.386 ; P=0.003$, $r: 0.186 ; P<0.001, r: 0.206$ and $P<0.001, r: 0.243$, respectively). There was found statistically significant negative correlation between the health anxiety inventory total score and the effect of COVID-19 outbreak on work life and social life $(P<0.001, r:-0.389$ and $P<0.001, r:-0.340$, respectively). As the social media readings about COVID-19 outbreak increased, the total score of the health anxiety inventory was found to be statistically significant $(P<0.001, r: 0.341)$. There was a strong positive correlation between the health anxiety inventory total score and the physical symptoms sub-score and the negative results of the disease sub-score $(P<0.001$, r:0.951 and $P<0.001, r: 0.692$, respectively) (Table 4).

Comparison of the participants by profession groups is shown in Table 5. Compared to other health personnel (OHP) groups, the rate of exchanging excessive food materials was significantly higher in doctor and nurse groups $(p=0.005$ and
Table 2. The responses of the participants to the questions about the COVID-19 outbreak

\begin{tabular}{lc} 
& $\begin{array}{c}\text { Participants (n=293) } \\
\text { N (\%) }\end{array}$ \\
\hline $\begin{array}{l}\text { COVID-19 test status } \\
\text { yes }\end{array}$ & $4(1.4)$ \\
no & $289(98.6)$ \\
\hline $\begin{array}{l}\text { Psychiatric illness before COVID-19 } \\
\text { yes }\end{array}$ & $33(11.3)$ \\
no & $260(88.7)$ \\
\hline $\begin{array}{l}\text { Psychiatric support status in COVID-19 outbreak } \\
\text { yes }\end{array}$ & $59(20.1)$ \\
no & $234(79.9)$ \\
\hline Active working status in COVID-19 service & \\
yes & $83(28.3)$ \\
no & $210(71.7)$
\end{tabular}

Problems in childcare in COVID-19 outbreak $(\mathrm{N}=182)$

yes $\quad 99(54.3)$

no $83(45.7)$

The person at home who is in the risk group COVID-19

yes $\quad 110(37.5)$

no $183(62.5)$

Chronic disease status

yes $52(17.7)$

no 241 (82.3)

Hand washing habit during COVID-19

more often $269(91.8)$

no change 24 (8.2)

Excessive food shopping during COVID-19

yes $154(52.6)$

no 139 (47.4)

Shopping excessive cleaning supplies during COVID-19

yes $186(63.5)$

no 107 (36.5)

The effect of COVID-19 outbreak on business life of the healthcare too much $113(38.6)$ evident $100(34.1)$ some $\quad 50(17.1)$

very little $14(4.8)$

does not affect at all 16 (5.5)

The effect of COVID-19 outbreak on social life

too much $\quad 82(28.0)$

evident $134(45.7)$

some $\quad 46(15.7)$

very little $20(6.8)$

does not affect at all 10 (3.4)

The effect of COVID-19 outbreak on working desire

decreased $142(48.5)$

increased 24 (8.2)

not changed $127(43.3)$

The effects of COVID-19 outbreak news on anxiety

increased

$226(77.1)$

decreased

$3(1.0)$

not changed

$64(21.8)$

Physical symptoms sub-score

$13.00(1-36)$

Negative results of the disease sub-score

$3.00(0-12)$

Health anxiety inventory total score 
Table 3. Comparison of participants according to working status in COVID-19 service

\begin{tabular}{|c|c|c|c|}
\hline & $\begin{array}{c}\text { COVID-19 } \\
\text { service } \\
\text { (n=83) N (\%) }\end{array}$ & $\begin{array}{c}\text { Not in COVID-19 } \\
\text { service } \\
(n=210) \mathrm{N}(\%)\end{array}$ & $\begin{array}{l}P \\
\text { value }\end{array}$ \\
\hline \multicolumn{3}{|l|}{ COVID-19 test status } & 0.882 \\
\hline yes & $1(1.2)$ & $3(1.4)$ & \\
\hline no & $82(98.8)$ & $218(98.6)$ & \\
\hline \multicolumn{3}{|c|}{ Psychiatric illness before COVID-19 } & 0.887 \\
\hline yes & $9(10.8)$ & $24(11.4)$ & \\
\hline no & $74(89.2)$ & $186(88.6)$ & \\
\hline \multicolumn{3}{|c|}{ Psychiatric support status in COVID-19 outbreak } & 0.289 \\
\hline yes & $20(24.1)$ & 39 (18.6) & \\
\hline no & $63(75.9)$ & $171(81.4)$ & \\
\hline $\begin{array}{l}\text { Problems in childcare in } \\
\text { COVID-19 outbreak }\end{array}$ & $\mathrm{n}=44(100)$ & $n=141(100)$ & 0.008 \\
\hline yes & $28(63.6)$ & $71(50.3)$ & \\
\hline no & $16(36.4)$ & $70(49.7)$ & \\
\hline \multicolumn{3}{|c|}{ The person who is in the COVID-19 risk group at home } & 0.226 \\
\hline yes & $27(32.5)$ & $83(39.5)$ & \\
\hline no & $56(67.5)$ & $127(60.5)$ & \\
\hline \multicolumn{3}{|l|}{ Chronic disease status } & 0.206 \\
\hline yes & $11(13.3)$ & $41(19.5)$ & \\
\hline no & $72(86.7)$ & $169(80.5)$ & \\
\hline \multicolumn{3}{|c|}{ Hand washing habit during COVID-19 } & 0.131 \\
\hline more often & $73(88.0)$ & $196(93.3)$ & \\
\hline no change & $10(12.0)$ & $14(6.7)$ & \\
\hline \multicolumn{3}{|c|}{ Excessive food shopping during COVID-19 } & 0.086 \\
\hline yes & $37(44.6)$ & $117(55.7)$ & \\
\hline no & $46(55.4)$ & $93(44.3)$ & \\
\hline \multicolumn{3}{|c|}{ Shopping excessive cleaning supplies during COVID-19 } & 0.650 \\
\hline yes & $51(61.4)$ & $135(64.3)$ & \\
\hline no & $32(38.6)$ & $75(35.7)$ & \\
\hline \multicolumn{3}{|c|}{ The effect of COVID-19 outbreak on business life } & 0.846 \\
\hline too much & $35(42.2)$ & $78(37.1)$ & \\
\hline evident & $23(27.7)$ & $77(36.7)$ & \\
\hline some & $16(19.3)$ & $34(16.2)$ & \\
\hline very little & $4(4.8)$ & $10(4.8)$ & \\
\hline does not affect at all & $5(6.0)$ & $11(5.2)$ & \\
\hline \multicolumn{3}{|c|}{ The effect of COVID-19 outbreak on social life } & 0.802 \\
\hline too much & $24(28.9)$ & $58(27.8)$ & \\
\hline evident & $39(47.0)$ & $95(45.5)$ & \\
\hline some & $10(12.0)$ & $36(17.2)$ & \\
\hline very little & $6(7.2)$ & $14(6.7)$ & \\
\hline does not affect at all & $4(4.8)$ & $7(2.9)$ & \\
\hline \multicolumn{3}{|c|}{ The effect of COVID-19 outbreak on working desire } & 0.218 \\
\hline decreased & $37(44.6)$ & $105(50.0)$ & \\
\hline increased & $4(4.8)$ & $20(9.5)$ & \\
\hline not changed & $42(50.6)$ & $85(40.5)$ & \\
\hline \multicolumn{3}{|c|}{ The effects of COVID-19 outbreak news on anxiety } & 0.046 \\
\hline increased & $59(71.1)$ & $167(79.5)$ & \\
\hline decreased & $0(0.0)$ & $3(1.4)$ & \\
\hline not changed & $24(28.9)$ & $40(19.0)$ & \\
\hline Physical symptoms sub-score & $14.00(3-33)$ & $13.00(1-36)$ & 0.448 \\
\hline $\begin{array}{l}\text { Negative results of the disease } \\
\text { sub-score }\end{array}$ & $4.00(0-9)$ & $3.00(0-12)$ & 0.212 \\
\hline $\begin{array}{l}\text { Health anxiety inventory total } \\
\text { score }\end{array}$ & $17.00(3-37)$ & $16.00(1-44)$ & 0.276 \\
\hline
\end{tabular}

$p=0.010$, respectively). Compared to the doctor group, the rate of receiving psychiatric support in COVID-19 outbreak was statistically significantly higher in the nurse and OHP group ( $p=0.007$ and $p=0.013$, respectively). Compared to the doctor and OHP group, the rate of active employees in the COVID-19 outpatient clinic / service was found to be statistically significantly higher in the nurse group $(p<0.001$ and $p<0.001$, respectively). Compared to the doctor group, it was found that the COVID-19 pandemic affected the work life statistically significantly more in the nurse group $(p=0.043)$. Compared to the doctor group, the effect of COVID-19 pandemic on social life was found to be statistically significant in the nurse and OHP group $(p=0.007$ and $p<0.003$, respectively). Compared to the doctor group, the physical symptoms sub-score was found to be statistically significantly higher in the OHP group ( $p=0.006$ and $p=0.001$, respectively). However, the total score of the health anxiety inventory was found to be statistically significantly higher in the nurse and OHP group compared to the doctor group $(p=0.013$ and $p=0.005$, respectively) (Table 5).

Table 4. Correlation analysis between the participants' health anxiety inventory total score and inventory sub-scores, business and social life effects

\begin{tabular}{|c|c|}
\hline & $\begin{array}{c}\text { Health anxiety } \\
\text { inventory total } \\
\text { score }\end{array}$ \\
\hline Psychiatric support status in COVID-19 outbreak & $\begin{array}{l}P<0.001 \\
\mathrm{r}: 0.386^{* * *}\end{array}$ \\
\hline Hand washing habit during COVID-19 & $\begin{array}{l}P=0.003 \\
r: 0.186^{* *}\end{array}$ \\
\hline Excessive food shopping during COVID-19 & $\begin{array}{l}P<0.001 \\
r: 0.206^{* *}\end{array}$ \\
\hline $\begin{array}{l}\text { Shopping excessive cleaning supplies during } \\
\text { COVID-19 }\end{array}$ & $\begin{array}{l}P<0.001 \\
r: 0.243^{* *}\end{array}$ \\
\hline The effect of COVID-19 outbreak on business life & $\begin{array}{l}P<0.001 \\
\text { r:- } 0.389^{* *}\end{array}$ \\
\hline The effect of COVID-19 outbreak on social life & $\begin{array}{l}P<0.001 \\
\text { r:- } 0.340^{* *}\end{array}$ \\
\hline The effect of COVID-19 outbreak on working will & $\begin{array}{l}P<0.001 \\
\text { r:- } 0.344^{* *}\end{array}$ \\
\hline The effects of COVID-19 outbreak news on anxiety & $\begin{array}{l}P<0.001 \\
\mathrm{r}: 0.341^{* *}\end{array}$ \\
\hline Physical symptoms sub-score & $\begin{array}{l}P<0.001 \\
r: 0.951^{* *}\end{array}$ \\
\hline Negative results of the disease sub-score & $\begin{array}{l}P<0.001 \\
\mathrm{r}: 0.692^{* *}\end{array}$ \\
\hline Chronic disease status & $p>0.05$ \\
\hline COVID-19 test status & $p>0.05$ \\
\hline Problems in childcare in COVID-19 outbreak & $\mathrm{p}>0.05$ \\
\hline Psychiatric illness before COVID-19 & $p>0.05$ \\
\hline Active working status in COVID-19 service & $p>0.05$ \\
\hline $\begin{array}{l}\text { The person at home who is in the risk group } \\
\text { COVID- } 19\end{array}$ & $p>0.05$ \\
\hline
\end{tabular}




\begin{tabular}{|c|c|c|c|c|}
\hline & $\begin{array}{c}\text { Doctor } \\
(n=73) \\
N(\%)\end{array}$ & $\begin{array}{c}\text { Nurse } \\
(n=145) \\
N(\%)\end{array}$ & $\begin{array}{c}\text { OHP (n=75) } \\
\text { N (\%) }\end{array}$ & $P$ value \\
\hline \multicolumn{4}{|l|}{ COVID-19 test status } & 0.457 \\
\hline yes & $1(1.4)$ & $1(2.1)$ & $0(0)$ & \\
\hline no & $72(98.6)$ & $142(97.9)$ & $75(100)$ & \\
\hline \multicolumn{4}{|c|}{ Psychiatric illness before COVID-19 } & 0.061 \\
\hline yes & $7(9.6)$ & $12(8.3)$ & $14(18.7)$ & \\
\hline no & $66(90.4)$ & $133(91.7)$ & $61(81.3)$ & \\
\hline \multicolumn{4}{|c|}{ Psychiatric support status in COVID-19 outbreak } & 0.005 \\
\hline yes & $5(6.8)$ & $35(24.1)$ & $19(25.3)$ & \\
\hline no & $68(93.2)$ & $110(75.9)$ & $56(74.7)$ & \\
\hline \multicolumn{4}{|c|}{ Active working status in COVID-19 service } & $<0.001$ \\
\hline yes & $11(15.1)$ & $61(42.1)$ & $11(14.7)$ & \\
\hline no & $62(84.9)$ & $84(57.9)$ & $64(85.3)$ & \\
\hline \multicolumn{4}{|c|}{ Problems in childcare in COVID-19 outbreak } & 0.167 \\
\hline yes & $24(47.0)$ & $47(55.2)$ & $28(57.2)$ & \\
\hline no & $27(53.0)$ & $38(44.8)$ & $21(42.8)$ & \\
\hline \multicolumn{4}{|c|}{ The person at home who is in the risk group COVID-19 } & 0.942 \\
\hline yes & $28(38.4)$ & $53(36.6)$ & $29(38.7)$ & \\
\hline no & $45(61.6)$ & $92(63.4)$ & $46(61.3)$ & \\
\hline \multicolumn{4}{|l|}{ Chronic disease status } & 0.421 \\
\hline yes & $11(15.1)$ & $24(16.6)$ & $17(22.7)$ & \\
\hline no & $62(84.9)$ & $121(83.4)$ & $58(77.3)$ & \\
\hline \multicolumn{4}{|c|}{ Hand washing habit during COVID-19 } & 0.393 \\
\hline more often & $68(93.2)$ & $130(89.7)$ & $71(94.7)$ & \\
\hline no change & $5(6.8)$ & $15(10.3)$ & $4(5.3)$ & \\
\hline \multicolumn{4}{|c|}{ Excessive food shopping during COVID-19 } & 0.003 \\
\hline yes & $45(61.6)$ & $82(56.6)$ & $27(36.0)$ & \\
\hline no & $28(38.4)$ & $63(43.4)$ & $48(64.0)$ & \\
\hline \multicolumn{4}{|c|}{ Shopping excessive cleaning supplies during COVID-19 } & 0.439 \\
\hline yes & $50(68.5)$ & $87(60.0)$ & $49(65.3)$ & \\
\hline no & $23(31.5)$ & $58(40.0)$ & $26(34.7)$ & \\
\hline \multicolumn{4}{|c|}{ The effect of COVID-19 outbreak on business life } & 0.045 \\
\hline too much & $22(30.1)$ & $61(42.1)$ & $30(40.0)$ & \\
\hline evident & $22(30.1)$ & $49(33.8)$ & $29(38.7)$ & \\
\hline some & $19(26.0)$ & $24(16.6)$ & $7(9.3)$ & \\
\hline very little & $4(5.5)$ & $6(4.1)$ & $4(5.3)$ & \\
\hline does not affect at all & $6(8.2)$ & $5(3.4)$ & $5(6.7)$ & \\
\hline \multicolumn{4}{|c|}{ The effect of COVID-19 outbreak on social life } & 0.002 \\
\hline too much & $11(15.1)$ & $43(29.7)$ & $28(37.3)$ & \\
\hline evident & $33(45.2)$ & $69(47.6)$ & $32(42.7)$ & \\
\hline some & $16(21.9)$ & $22(15.2)$ & $8(10.7)$ & \\
\hline very little & $10(13.7)$ & $7(4.8)$ & $3(4.0)$ & \\
\hline does not affect at all & $3(4.1)$ & $4(2.8)$ & $3(4.0)$ & \\
\hline \multicolumn{4}{|c|}{ The effect of COVID-19 outbreak on working desire } & 0.900 \\
\hline decreased & $36(49.3)$ & $71(49.0)$ & $35(46.7)$ & \\
\hline increased & $8(11.0)$ & $8(5.5)$ & $8(10.7)$ & \\
\hline not changed & $29(39.7)$ & $66(45.5)$ & $32(42.7)$ & \\
\hline \multicolumn{4}{|c|}{ The effects of COVID-19 outbreak news on anxiety } & 0.773 \\
\hline increased & $60(82.2)$ & $110(75.9)$ & $56(74.7)$ & \\
\hline decreased & $0(0.0)$ & $2(1.4)$ & $1(1.3)$ & \\
\hline not changed & $13(17.8)$ & $33(22.8)$ & $18(24.0)$ & \\
\hline $\begin{array}{l}\text { Physical symptoms } \\
\text { sub-score }\end{array}$ & $11.0(2-21)$ & $14.0(1-29)$ & $14.0(1-36)$ & $<0.001$ \\
\hline $\begin{array}{l}\text { Negative results of } \\
\text { the disease sub-score }\end{array}$ & $3.0(0-8)$ & $3.0(0-12)$ & $3.0(0-9)$ & 0.419 \\
\hline $\begin{array}{l}\text { Health anxiety } \\
\text { inventory total score }\end{array}$ & $15.0(4-25)$ & $17.0(2-35)$ & $18.0(1-44)$ & 0.003 \\
\hline
\end{tabular}

\section{DISCUSSION}

Our study is the first study in our country to evaluate the health concerns of COVID-19 outbreak and their effects on life in healthcare workers. In our study, it was determined that the COVID-19 test was performed to the healthcare personnel in the risk group at a very low rate (1.4\%), had a low level of psychiatric support (54.3\%), had a low level of desire to work $(48.5 \%)$, and increased health anxiety. Accordingly, it has been determined that health workers have increased habit of hand washing $(91.8 \%)$ and they have purchased excessive food and cleaning materials. These increases are probably due to increased excessive health anxiety. As the social media readings about COVID-19 outbreak increased, the total score of the health anxiety inventory was found to be statistically significant. In addition, it was determined that the COVID-19 pandemic negatively affected the business and social life of healthcare workers.

In the first study conducted in Wuhan with the outbreak of COVID-19, it was found that $71.3 \%$ of healthcare workers had mild psychiatric disorders in $22.4 \%$ and severe in $6.2 \% .10$ It was emphasized that accessing mental health services is important for healthcare professionals working in the pandemic, improving their physical health perceptions and alleviating their acute mental distress. ${ }^{[10]}$ To reduce COVID19 's mental damage among healthcare professionals, mental health professionals in Wuhan have provided a range of spiritual services, including providing intervention teams, providing brochures, counseling and psychotherapy. ${ }^{[1]}$ In our study, it was found that healthcare workers' health anxiety increased, their work and social life affected negatively at a very high level, and they felt the need to receive support from psychiatry professionals. It was determined that as the readings on social media about COVID-19 outbreak increased, health anxiety increased. Therefore, healthcare workers with a tendency to anxiety should stay away from COVID-19 outbreak news on social media. Compared to the not in COVID-19 service, it was determined that the employees working in the Covid-19 service received more support from the psychiatrist in the COVID-19 outbreak.

Various efforts have been made, such as providing more medical staff, adopting strict infection control, providing personal protective equipment and providing practical guidance to reduce pressure and work intensity on healthcare staff in China. ${ }^{[12]}$ Similarly, video interview programs, stress management programs, group programs aiming to communicate, talk, share experiences and express fear and hopes at the end of a working day have been launched to provide individual spiritual support for employees in COVID-19 units. ${ }^{[13]}$ In France, where casualties are frequent, psychiatric tele-consultation helplines have been set up to help mental and medical hospital staff who are exposed to overwork, stress, difficult ethical decisions, and multiple deaths to cope with the fear of contamination and contamination for themselves and their families. ${ }^{[14]}$ Compared to the rate of 
tests performed healthcare personnel in countries such as France and China; it was thought that the rate of COVID-19 test performed in the healthcare personnel working in the service where COVID is examined is quite low in terms of infection control in our country. In our study, group programs aiming to communicate, talk, share experiences and express fears and hopes should be expanded in the institutions, since the increase in health anxiety of health personnel (especially nurses and other health personnel) decreases the desire to work, negatively affects their business and social life.

In the study of Hyunsuk et al. ${ }^{[15]}$ on the epidemic of the Middle East Respiratory Syndrome (MERS), it was reported that most of the people in the risk group increased their spending on food and cleaning materials, experienced financial losses and psychiatric diseases due to their negative effects on their social lives. In our study, it was found that hand washing habit was more common in 269 (91.8\%) people, 154 (52.6\%) people purchased excessive food and 186 (63.5\%) people purchased excessive cleaning materials during the COVID-19 outbreak. These increases are probably due to increased excessive health anxiety. However, it was determined that the COVID-19 pandemic affected the business life of the healthcare personel very much in 113 (38.6\%) people, and significantly affected $100(34.1 \%)$ people $(p<0.05)$. It was determined that the COVID-19 pandemic affected the social life of the healthcare personnel very much in $82(28.0 \%)$ people, and significantly affected $134(45.7 \%)$ people $(p<0.05)$. In addition, it was found that COVID-19 pandemic affected the business life of the healthcare statistically significantly more in the nurse group compared to the doctor group. Compared to the doctor group, the effect of COVID-19 pandemic on social life was found to be statistically significant in the nurse and OHP group.

In a study conducted by Huang et al. ${ }^{[16]}$ with 230 health workers about the COVID-19 outbreak, it was reported that the health anxiety increased and the nurse staff's anxiety score was higher than that of the doctors. In our study, it was found that the physical symptoms sub-score and the health anxiety inventory total score were statistically significantly higher in the nurse and OHP group compared to the doctor group. We think that the reason why the nurse and OHP health anxiety is higher than the doctors is because the treatment and nursing operations may have been carried out by the nurse and OHP, because they worked longer in the isolation services than the doctors and had closer contact with the patients.

Several strengths and limitations of the study need to be mentioned. In the current study, our data consisted of a large sample size. Additionally, our study was carried on a community sample of health workers, which may limit the occurrence of confounding factors that result from comorbid psychopathologies when clinical samples are used. This is also the first study in our country to evaluate the health concerns of COVID-19 outbreak and their effects on life. Yet, the present study has also some limitations. First, in this study, self-report measures were used by online method and conducted in a single center. As known, self-report instruments are subject to social desirability, which can push responders to deny certain problems. Second, our study was cross-sectional, and a prospective study may be needed to confirm the causal relationships. Third, we had little information about baseline anxiety and depression levels of the study participants.

\section{CONCLUSION}

Current findings of our study enhance our understanding of the effects of COVID-19 outbreak on health workers' health concerns and life. Determining these negative effects of the outbreak on frontline health teams has an important role in giving an early and protective social, vocational and also psychiatric support. For future outbreaks like COVID-19, one of the issues that countries should be prepared for is to increase the online mental health services, to protect the mental health of the frontline health teams in order to provide a functional service, to protect the mental health, necessary protective and supportive spiritual, social measures need to be taken. Also carrying out some other new studies like this, in which a comprehensive assessment of different affected areas was used, might help have a better understanding and diversify supports.

\section{ETHICAL DECLARATIONS}

Ethics Committee Approval: The study was carried out with the permission of Sakarya University Faculty of Medicine Non-Invasive Trial Ethics Committee (Permission granted: 13.03.2020/114, Decision no: 71522473/050.01.04).

Informed Consent: All patients signed the free and informed consent form.

Referee Evaluation Process: Externally peer-reviewed.

Conflict of Interest Statement: The authors have no conflicts of interest to declare.

Financial Disclosure: The authors declared that this study has received no financial support.

Author Contributions: All of the authors declare that they have all participated in the design, execution, and analysis of the paper, and that they have approved the final version.

\section{REFERENCES}

1. Liu S, Yang L, Zhang C, et al. Online mental health services in China during the COVID-19 outbreak. Lancet Psychiatry. 2020;7(4):e17-e18.

2. Weiss SR, Leibowitz JL. Coronavirus pathogenesis. Adv Virus Res. 2011;81:85-164.

3. Liang WH, Guan WJ, Li CC, et al. Clinical characteristics and outcomes of hospitalised patients with COVID-19 treated in Hubei (epicentre) and outside Hubei (non-epicentre): a nationwide analysis of China. Eur Respir J. 2020;55(6):2000562.

4. Huang C, Wang Y, Li X, et al. Clinical features of patients infected with 2019 novel coronavirus in Wuhan, China [published correction appears in Lancet. 2020 Jan 30;:]. Lancet. 2020;395(10223):497-506. 
5. Xiang YT, Yang Y, Li W, et al. Timely mental health care for the 2019 novel coronavirus outbreak is urgently needed. Lancet Psychiatry. 2020;7(3):228-9. doi:10.1016/S2215-0366(20)30046-8.

6. Chan SS, So WK, Wong DC, Lee AC, Tiwari A. Improving older adults' knowledge and practice of preventive measures through a telephone health education during the SARS epidemic in Hong Kong: a pilot study. Int J Nurs Stud. 2007;44(7):1120-7.

7. Aydemir Ö, Kirpinar I, Sati T, Uykur B, Cengisiz C. Reliability and Validity of the Turkish Version of the Health Anxiety Inventory. Noro Psikiyatr Ars. 2013;50(4):325-31.

8. Norton PJ, Sexton KA, Walker JR, Norton GR. Hierarchical model of vulnerabilities for anxiety: replication and extension with a clinical sample. Cogn Behav Ther. 2005;34(1):50-63.

9. Salkovskis PM, Rimes KA, Warwick HM, Clark DM. The Health Anxiety Inventory: development and validation of scales for the measurement of health anxiety and hypochondriasis. Psychol Med. 2002;32(5):843-53.

10. Kang L, Ma S, Chen M, et al. Impact on mental health and perceptions of psychological care among medical and nursing staff in Wuhan during the 2019 novel coronavirus disease outbreak: A cross-sectional study. Brain Behav Immun. 2020;87:11-7. doi:10.1016/j.bbi.2020.03.028.

11. Kang L, Li Y, Hu S, et al. The mental health of medical workers in Wuhan, China dealing with the 2019 novel coronavirus. Lancet Psychiatry. 2020;7(3):e14. doi:10.1016/S2215-0366(20)30047-X

12. Khalid I, Khalid TJ, Qabajah MR, Barnard AG, Qushmaq IA. Healthcare Workers Emotions, Perceived Stressors and Coping Strategies During a MERS-CoV Outbreak. Clin Med Res. 2016;14(1):7-14.

13. Fagiolini A, Cuomo A, Frank E. COVID-19 Diary From a Psychiatry Department in Italy. J Clin Psychiatry. 2020;81 (3):20com13357. Published 2020 Mar 31. doi:10.4088/JCP.20com13357.

14. Corruble E. A Viewpoint From Paris on the COVID-19Pandemic: A Necessary Turn to Telepsychiatry. J Clin Psychiatry. 2020;81(3):20com13361. Published 2020 Mar 31. doi:10.4088/JCP.20com13361.

15. Jeong H, Yim HW, Song YJ, et al. Mental health status of people isolated due to Middle East Respiratory Syndrome. Epidemiol Health. 2016;38:e2016048.

16. Huang JZ, Han MF, Luo TD, Ren AK, Zhou XP. Zhonghua Lao Dong Wei Sheng Zhi Ye Bing Za Zhi. 2020;38(3):192-195. doi:10.3760/ cma.j.cn121094-20200219-00063. 